\title{
SOCIALINIS DARBAS IR GALIA: TEORINIAI TYRINĖJIMŲ PAGRINDAI
}

\author{
BIRUTE் ŠVEDAITE்-SAKALAUSKE், \\ JOLITA BUZAITYTÉ-KA ŠALYNIENE், \\ LIJANA GVALDAITÉ \\ VILNIAUS UNIVERSITETAS
}

Straipsnyje pristatomos keturios skirtingos galios teorinés paradigmos (M. Weberio galios apibrëžtis, N. Eliaso galios balansu teorija, lošimu teorijos bei socialiniu mainu teorijos požiüris i galia, sisteminè-konstruktyvistiné galios koncepcija), siekiant atverti galimybes galios fenomeno dirbant socialini darba empirinei analizei. Taip pat straipsnyje išryškinamos esminès socialinio darbo galios formos ir priemonés: fizine galia, ekonominè galia, autoriteto, arba santykio galia, poziciné, arba organizacine galia bei žinojimo/definicijos galia.

\section{IVADAS}

Pagalba, kad ir kokia ji būtų, visuomet savyje slepia galią ir priklausomybę: kažkam reikia pagalbos, taigi jis ar ji yra silpnesnis (-è) ir priklausomas (-a), o kitas ar kita - gali (turi galią) pagalbą suteikti, vadinasi, turi išteklių, gebẻjimų, galiausiai, norą ar motyvą padèti. Todèl socialinis darbas, būdamas pagalbos profesija, visuomet susijęs su galia ir galios santykiais. Vis dèlto ne visada mielai pripažistama, o juo labiau atvirai analizuojama, kad šios profesijos kontekstas - galbūt dèl jos vertybinès orientacijos (nes galios sąvoka nebūtinai kelia simpatijas) - yra galia 
ir galios santykiai. ${ }^{1}$ Lietuvoje socialinio darbo ir galios tema iki šiolei iš viso neliesta - nei moksliniu, nei praktiniu lygmeniu. Kita vertus, lietuviškasis socialinis darbas labai jaunas, vis dar bandantis susivokti savyje, o ir apskritai Lietuvos viešajame diskurse itin reti gilesni galios reiškinių tyrinèjimai².

Nors kasdienybejje galios sąvoka dažniausiai turi neigiamą atspalvị (beje, pats žodis "galia“" galbūt nėra toks dažnas, bet galia turima mintyje, kai kalbama apie "spaudimą", "prievartą", "neturèjimą kitos išeities", „pasirinkimo neturèjimą“, „neteisybę", „neteisingą valdžią“ ir pan.), teoriniu lygmeniu šiandien sutariama, kad galia pati savaime nèra nei gera, nei bloga, - tarp žmoniu, ypač jiems komunikuojant, ji pasireiškia visada. Anot H. Popitzo (cit. Kraus, Krieger, 2011, 10), „sterilizuotų santykių, santykių be galios" nebūna. "Galia atsiranda visada, kai tik žmonès suderina savo elgesi tarpusavyje ir sukuria socialinę tvarką" (Kraus, Krieger, 2011, 10) - taigi kai atsiranda taisyklès, kai pasidalijama kompetencijomis ar atsakomybėmis, kai prisiimami vaidmenys, kai paskirstomi ištekliai, kai igyjamos teisès ir pan. Tad galia esant pagalbos santykiams - socialinio darbuotojo ir kliento sąveikai - natūrali ir neišvengiama duotybė. Kaip tik dèl to ji ir turi būti nuolatinis refleksiju objektas. Kita vertus, galia dirbant socialinị darbą pasireiškia ne vien socialiniam darbuotojui tiesiogiai sąveikaujant su klientu (-ais). Ji veikia ir yra reikšmingas „žaidejjas“ socialinio darbo organizavimo lygmeniu: organizacijų viduje, kai mezgami darbuotojų ir vadovų, specialistų komandu narių santykiai, tarpinstituciniu lygmeniu ir t. t. Taip pat visos visuomenės mastu, kai aptariami socialinio darbo siekiai, šiai profesijai deleguojami uždaviniai, jos veikimo kryptys, politika, prestižas ir pan. taigi kai kalbama apie profesijos galią (galbūt jos negalią?) visuomenėje.

\footnotetext{
${ }^{1}$ Išimtis yra Vakarų visuomenių šeštojo-septintojo dešimtmečio vadinamosios studentu revoliucijos laikai: tuo metu - kritinės teorijos klestejjimo laiku - buvo itin kritiškai ir daug diskutuojama apie galia, galios struktūras, galinguosius ir begalius, socialinę nelygybę ir pan. Aršios kritikos susilaukè ir socialinio darbo ekspertizmas (juo demonstruojama galia). Suprantama, tuometinėse galios diskusijose "galios" sąvoka dažniausiai buvo suprantama neigiama prasme.

${ }^{2}$ Išskyrus kelis pavienius atvejus, pvz., J. Ruškaus ir G. Mažeikio atliktus neigalumo ir socialumo tyrinejjimus (Ruškus, J., Mažeikis, G. Neigalumas ir socialinis dalyvavimas. 2007) arba R. Žiliukaitès ir kt. Lietuvos pilietinès visuomenès tyrimas (Neatrasta galia. 2006).
} 
Taigi ryškëja bent trys galios dirbant socialinį darbą analizės lygmenys: mikrolygmuo (interakcijos lygmuo), mezolygmuo (organizacijos lygmuo) ir makrolygmuo (visuomenès lygmuo), kurie galètų ir tikriausiai privalètų būti diskutuojami, galvojant ne vien apie praktikos plètotę, profesijos ir profesionalumo ugdyma, bet ir apie socialinio darbo mokslinių tyrinèjimų raidą. Tad šio straipsnio tikslas yra pateikti potencialių galios dirbant socialini darbą tyrinèjimų (teorinių bei empirinių) teorinius pagrindus, apibrèžiant esmines sąvokas bei atveriant skirtingu teoriniu prieigu galimybes. Siekiant straipsnio tikslo, pirmiausia pristatomos įvairios teorinès perspektyvos ir ju galios traktuotès ${ }^{1}$, vèliau svarstoma galios šaltiniai, formos ir priemonės dirbant socialini darbą. Straipsnis parengtas vykdant Lietuvos mokslo tarybos finansuotą projektą "Socialinis darbas: tarp priklausomybės ir autonomijos" (projekto nr. SIN-04/2012/LSS-250000-620).

\section{TEORINÉS GALIOS PARADIGMOS}

\section{WEBERIO GALIOS SAMPRATA}

M. Weberio klasikiniu tapęs galios apibrèžimas² skamba taip:

„Galia reiškia bet kokị šansą socialiniame ryšyje realizuoti savo valią taip pat ir tuo atveju, kai susiduriama su pasipriešinimu, - nesvarbu, kuo tas šansas remtųsi“ $(1976,28)^{3}$.

Taigi M. Weberiui galia visų pirma pasireiškia esant santykiui - be konkretaus santykio negali būti galios. Kitas svarbus momentas, kad M. Weberis kalba apie šansa, bet ne apie pati veiksma, t. y. galios igyvendinimą. Anot P. Baumanno (1993), šansas dar neužtikrina, kad galia bus pasinaudota, kad ji bus igyvendinta. Tačiau kas turi šansa, tas greičiausiai turi ir resursu galiai igyvendinti. Todèl galima teigti, kad M. Weberiui galia yra socialiai nevienodai padalyti šansai. Taigi galios

\footnotetext{
${ }^{1}$ Dèl ribotos straipsnio apimties neįmanoma aptarti visų ryškiausių galios teorijų, todèl straipsnio autorès apsiribojo keturiomis, jų nuomone, galinčiomis labai padèti galios vykdant socialinį darbą analizuotojams.

2 Esminis M. Weberio veikalas apie galią yra „Wirtschaft und Gesellschaft: Grundriss der verstehenden Soziologie" (pirmą kartą publikuotas 1921-1922 m.).

${ }^{3}$ Apibrèžimo vertimas į lietuvių kalbą yra Z. Norkaus, pateiktas straipsnyje „Du galios veidrodžiai“ (1998).
} 
santykiai yra asimetriniai - vieni tų šansų turi daugiau nei kiti. Kitas M. Weberio apibrèžties aspektas yra konfliktas tarp galią turinčiųu ir neturinčiujjų: konfliktas gali įvykti, tačiau gali ir neivvykti. Jei galingojo norui niekas nesipriešina, netgi atvirkščiai, - jam pritaria, visiškai nereiškia, kad jis savo turimą galią praranda. Galia pasireiškia ne vien esant pasipriešinimui, bet ir jam nesant.

M. Weberio galios apibrèžti taikant socialinio darbo kontekstui, svarbu nustatyti, kokiam konkrečiai santykiui esant galios fenomenai apskritai pasireiškia ir kaip tam santykiui esant socialiai paskirstyti galios šansai. Esant socialinio darbuotojo ir kliento santykiui, socialinis darbuotojas galios šansų turi tuomet, jei jie jam yra suteikti aukštesnès valdžios (pvz., spręsti, ar konkretiems asmenims turètų būti apribota jų teisė i jų vaikus). Jei socialinis darbuotojas tokių igaliojimų neturi, klientas gali su juo bendradarbiauti, tačiau lygiai taip pat jis gali nuspręsti nepaisyti socialinio darbuotojo ir jo bandymų užmegzti pagalbos santykị, ypač, jei nemato tokio santykio prasmės ar naudos. Pastaruoju atveju situacija apvirsta aukštyn kojomis - daugiau galios šansų turi klientas, o ne socialinis darbuotojas, nes anas ji gali „nubausti“ nebendradarbiavimu, ignoravimu ir pan. Visa tai išryškina dar du svarbius veberiškojo apibrèžimo aspektus: santykis tarp abiejų pusių turi būti priklausomybės santykis (kažkuris nuo kažkurio turi priklausyti labiau), o kitas aspektas yra tai, kad M. Weberio galios apibrèžimas tinka tuomet, jei bijomasi kažkokios sankcijos - taigi jo galios apibrezžimas galbūt yra daugiau sankcijos galios apibréžtis. Už ką M. Weberio galios samprata susilaukia kritikos? Esą ji per siaura, labiau akcentuoja sankcijos aspekta, tačiau, pavyzdžiui, nepaaiškina motyvacijos galios ir pan. (Baumann, 1993). Kita vertus, Weberio apibrèžime sakoma: „nesvarbu, kuo remiasi galios šansai“. Jie gali remtis, tarkime, vadinamuoju autoritetu (pvz., socialinis darbuotojas klientui yra autoritetas, todèl jis gali pasiekti, kad klientas, net ir nelabai norẻdamas, kažką padarytų, paklūstų), tačiau ir tuomet galia yra įmanoma tik todèl, kad mažiau galingas žmogus bijosi sankcijos - pvz., prarasti gerą santyki su socialiniu darbuotoju, jo palankumą ir pan.

Suprantama, kad veberiškoji galios apibrèžtis gali būti pasitelkiama ne vien analizuojant kliento - socialinio darbuotojo interakcijas, bet ir kitus socialinių darbuotojų santykius - organizacijose, tarpžinybiniuose tinkluose, su tarpdisciplininių komandų nariais, su bendruomenèmis, galiausiai - analizuojant socialinio darbo profesijos galios šansus visuomenèje. 


\section{GALIA IR GALIOS BALANSAI PAGAL N. ELIASA}

N. Eliaso galios samprata tiesiogiai nukreipta i priklausomybės santykį: „Jei mes labiau priklausome nuo kitų nei jie nuo mūsų, jei jų mums labiau reikia nei jiems mūsuz, jie turi mums galią. Nesvarbu, ar mes tapome nuo jų priklausomi dèl grynos prievartos, ar dèl mūsų meilès, ar dèl mūsų poreikio būti mylimiems, ar dèl mūsų pinigų, sveikatos, statuso, karjeros, i̇vairesnio gyvenimo poreikio“1 $(1986,97)$.

Taigi N. Eliaso galios samprata nurodo žmonių tarpusavio priklausomybę, kita vertus, joje kalbama apie galios priežastis - dẻl ko siekiame galios ar esame priklausomi nuo galingųjų? Ogi dèl savo poreikių. Poreikiai yra mūsų tarpusavio priklausomybių šaltinis. Kadangi poreikiai nuolat kinta, kinta ir mūsų tarpusavio priklausomybės, nauji poreikiai sukuria naujas tarpusavio priklausomybes, o senieji poreikiai ir anksčiau buvę svarbūs tarpusavio santykiai praejjus laikui galbūt nebėra tokie svarbūs (plg. Wolf, 2011, 122).

Vis dèlto galia atsiranda tuomet, kai žmonès vienas nuo kito priklausomi nevienodai: silpnesnis yra tas, kuris labiau priklausomas, ir atvirkščiai stipresnis yra mažiau priklausomas. Taigi galios atveju esminis dalykas yra priklausomybės tarp dviejų subjektų skirtumas (Wolf, 2011). Tokius skirtumus N. Eliasas (1986) vadina galios diferencialais. Tačiau pasidaro dar aiškiau, kai įsigiliname ị N. Eliaso galios balansų koncepciją.

K. Wolfas (2011, 122 ir toliau), tyrinėjęs socialinio darbo klausimus N. Eliaso teorijos pagrindu, galios balansus apibūdina šiais keturiais aspektais:

1) Galia tarp dviejų ar daugiau žmonių yra padalyta nevienodai - vieni jos turi daugiau, kiti mažiau (galios diferencialai), tačiau šis galios skirtumas nereiškia, kad mažiau galios turintys žmonès (ar grupès) visiškai netenka galios. Jie taip pat turi galia, tačiau yra labiau priklausomi nuo pirmujų nei anie nuo jų. Tad analizès klausimas nèra, kas turi galia (nes galią turi ir vieni, ir kiti), klausimas yra kiek labai vieni yra priklausomi nuo

\footnotetext{
1 „Insofern als wir mehr von anderen abhaengen als sie von uns, mehr auf andere angewiesen sind als sie auf uns, ob wir nun durch nackte Gewalt von ihnen abhaengig geworden sind oder durch unsere Liebe oder durch unser Beduerfnis, geliebt zu werden, durch unser Beduerfnis nach Geld, Gesundung, Status, Karriere und Abwechslung."
} 
kitu. Šis aspektas parodo, kad priklausomybę jaučia ne vien mažesnę galią turintieji, bet ir galingasis (-ieji).

2) Nevienodas galios pasiskirstymas nèra statiškas, jis gali kisti, tad galios balansai yra "elastiški“ - jie gali būti trumpalaikiai, nestabilūs arba ilgalaikiai, pakankamai stabilūs, keistis labai nežymiai. Tad, kaip pabrèžia K. Wolfas, jų negalima suprasti kaip būsenos, tai - nuolatinis procesas.

3) Galios balanso pasikeitimai gali vykti dèl labai įvairių priežasčių. Dauguma priežasčių gali išaiškėti tik žvelgiant i̇ visą asmenų tarpusavio priklausomybių tinklą. Kai kurios galios balanso pasikeitimo priežastys gali būti susijusios su visos visuomenès vystymosi tendencijomis (pvz., galios diferencialų sumažėjimas tarp tėvų ir vaikų, palyginti su ankstesnėmis visuomenėmis: šiandien tapo norma atsižvelgti $\mathfrak{i}$ vaiko poreikius, jo nuomonę, o vaiko mušimas nèra pateisinama auklëjimo priemonè, mušimas netgi laikomas smurtu, o ankstesniais laikais tai nebūtų buvę suprantama. Vakarų visuomenejje panašiai keitèsi ir vyrų bei moterų santykių galios diferencialai.

4) Galios pusiausvyra yra daugiau ar mažiau stabilus arba, atvirkščiai, labilus vienas kita neutralizuojančiu poveikiu rezultatas. Tai reiškia, jog susiduria dvi vienodo stiprumo priklausomybės: abi pusės viena nuo kitos yra vienodai stipriai (arba vienodai silpnai) priklausomos, todèl atsiranda galios pusiausvyra, o galios diferencialo nebelieka.

İsigilinus i šiuos keturis aspektus tampa aišku, kad galios pusiausvyra nèra tas pat, kas galios balansas. Galios pusiausvyra atsiranda tik tuomet, kai priklausomybè tarp partnerių (ar grupių) yra vienodo stiprumo, visais kitais atvejais - kai priklausomybe netolygi egzistuoja galios balansai. İdomu, kad N. Eliasas, siekdamas apibūdinti nevienodai pasiskirsčiusią galia, nevienodai išreikštas priklausomybes, pasirenka būtent balanso metaforą. Galbūt šitaip norima atkreipti dèmesi, kad galia yra nuolatinis žmonių tarpusavio santykius veikiantis reiškinys, tačiau jis yra paslankus, procesinis, nuolat kintantis - tai nuolatinis tarpusavio priklausomybių tinklo balansavimas (vienoje vietoje persiskirstęs galios balansas sukels reakcijas ir darys poveiki kitiems priklausomybių santykiams). N. Eliasas teigia: „Galios balansai yra mažiausiai bipoliariniai ir dažniausiai multipoliariniai fenomenai“ $(1986,77)$. Taigi galios balansai paprastai 
neapsiriboja paprasta diada, jie yra kompleksinis ir procesinis reiškinys. Kaip matyti, jiems poveiki gali turèti tiek tarpasmeninio santykio pokyčiai, tiek galios pokyčiai mezomastu bei makromastu. Kita vertus, K. Wolfas (1999) pabrèžia, kad balanso metaforos koncepcija jokiu būdu ne normatyvinè, taigi N. Eliaso tikslas - ne kritikuoti galios diferencialus ir siekti galios pusiausvyros, o pasiūlyti galios balansų apibrèžti, siekiant diferencijuotos galios santykių analizès.

N. Eliaso galios teorija mums leidžia apie socialinį darbą mąstyti tarpusavio priklausomybiu aspektu ir tas priklausomybes analizuoti. Pvz., kliento ir socialinio darbuotojo santykị: kuris nuo kurio labiau priklausomas ir kaip kinta jų galios balansas vykstant pagalbos procesui, galbūt net (tam tikrame etape) pasiekia galios pusiausvyrą. Tačiau lygiai taip pat galima analizuoti ir socialinio darbuotojo profesines priklausomybes nuo kitų institucijų ar specialistų sprendimų (pvz., socialinis darbuotojas, dirbantis su rizikos šeima, yra labiau priklausomas nuo Vaiko teisių apsaugos skyriaus sprendimų nei pastarasis nuo jo - visa tai turi poveikị pagalbos procesui). Taigi N. Eliaso galios balansų teorija leidžia ì socialinị darbą žvelgti kaip ị tarpusavio priklausomybių daugiadimensinį tinkla, kuriame vienos tinklo vietos galios balansai (pvz., vykstant tarpinstituciniam bendradarbiavimui) atsiliepia kitos tinklo vietos galios santykiams (pvz., socialinio darbuotojo santykiui su klientu). Svarbu prisiminti, kad N. Eliaso galios balansų teorija i analizès lauką leidžia įtraukti ir visuomenės mastu vykstančius pokyčius. Jau minèta apie modernioje visuomenëje nusistovëjusi kitokį vaikų ir suaugusiujuu, vyrų ir moteru galios diferencialą. Visuomenès vystymosi tendencijos turi įtakos ir socialiniam darbui, nes kinta paslaugos gavejo ir paslaugos teikejjo, eksperto ir pagalbą gaunančiojo galios balansas. Šiandien socialinis darbuotojas nebèra vien geraširdis, daugiau išmanantis patarèjas, o klientas nebėra vien nuolankus ir dèkingas už pagalbą žmogus kaip anksčiau. Socialinio darbuotojo pastangos yra priklausomos nuo kliento pasirengimo bendradarbiauti. Paslaugas gauti nèra privaloma (išskyrus kelis atvejus), jos priimamos savo noru ir t. t. Daug pasikeitimų yra įvykę ir darbinių santykių vadybos lygmeniu - ypač modernių socialiniu paslaugų kontekstu vis mažiau laikoma ir toleruojama įsakymų ir paklusnaus vykdymo vadybinè kultūra, vis daugèja lygiaverčio bendradarbiavimo, komandinio darbo tendenciju ir pan. Visa tai taip pat veikia socialinio darbo organizavimo tikrovę ir leidžia ją analizuoti 
būtent šiuo aspektu. N. Eliasas teigia (cit. pgl. Wolf, 1999, 128): „Jei galios diferencialas tarp dviejų skirtingų lygmenų grupių sumažèja (...), tuomet galios balansas tampa labilesnis ir elastiškesnis. Jis turi didesni polinki slinktis i vieną ar kitą pusę". Likime prie pavyzdžio apie vadovus ir jų pavaldinius: kuo jų galios skirtumas mažesnis, tuo galios balansai elastiškesni (vadovas paklūsta socialinio darbuotojo kaip profesionalo nuomonei, ne vien tik socialinis darbuotojas paklūsta vadovo sprendimams). Taigi sprendimai turi būti aptarti ir suderèti, ne įsakyti. Visa tai N. Eliasas susieja su informalizavimo procesu (cit. Wolf, 1999): atsiranda daugiau laisvės, tačiau dèl tos laisvès turi būti informaliai susitarta, o tai nauja ir kitokio pobūdžio tarpusavio priklausomybè. Be to, laisvè ir informalizavimo procesas pagimdo ir didesnę atsakomybę - šiuo atveju socialinio darbuotojo atsakomybę (ne vien paklusniai vykdyti, bet kurti, inicijuoti ir už tai atsakyti) ${ }^{1}$.

\section{LOŠIMŲ TEORIJA, SOCIALINIŲ MAINŲ TEORIJA IR GALIOS SAMPRATA}

Socialinių mainų teorija, lošimų teorija dėmesi taip pat sutelkia ì tarpusavio priklausomybę, tik kitu aspektu. Sprendimai, laimejjimai (ir pralaimejjimai) bei galia priklauso ne vien nuo asmeninių išteklių, bet ir

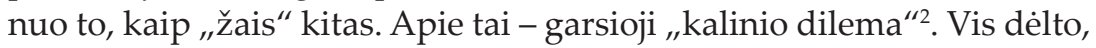
„kalinio dilema“ veikia tuomet, kai abieju situacija, starto pozicijos ar resursai yra vienodi (abu sėdi kalejime ir abu nežino, kaip elgsis kitas).

\footnotetext{
1 Lietuvoje iš socialinių darbuotoju dažnai girdèti, kad jų nepaiso kitos institucijos, „nuleidžia“ jiems neadekvačias užduotis ir pan. Visa tai liudija-N. Eliaso teorijos kontekste - apie galios diferenciala, kad socialiniai darbuotojai jaučiasi labiau priklausomi nuo kitų nei anieji nuo socialinių darbuotojų. Tai būtų i̇domi ir svarbi tyrinejjimų sritis. Kitą vertus, N. Eliasas teigia, kad „norima pažanga kartais gali turèti nenorimas pasekmes" (Elias 1977, cit. Wolf, 1999, 128), nes ji veda prie naujų socialinių ir asmeninių i̇tampų. Šiuo požiūriu būtų įdomu svarstyti: jei galios balansas pasikeistų socialinių darbuotojų naudai, kiek jie būtų pasirengę (gebejjimų, žinių, norų, motyvacijos ir t. t. prasme) žymiai didesnei atsakomybei, kūrybiškumui, rizikai ir profesionalumo demonstravimui?

${ }^{2}$ Kalinio dilema - tai istorija apie du kalinius, kurie kartu padare nusikaltimą ir yra tardomi atskirai. Jiems ịvardijamos sąlygos: jei vienas prisipažins, o kitas ne - pirmasis gaus, pvz., 2 metus, o antrasis - 12 metų; jei abu prisipažins - kiekvienas gaus po 4 metus; jei abu neprisipažins - kiekvienas gaus po 3 metus. Abiem kaliniams geriausia bendradarbiauti ir neprisipažinti, tačiau šis variantas retai pasirenkamas, nes kiekvienas pirmiausia žiūri savo interesu, tikèdamas, kad ir kitas pirmiausia stengsis dẻl savo naudos. Šią dilemą išsamiai analizavo J. Nashas.
} 
Realybejje retai sutinkama tokia tolygi situacija, dažniausiai resursai yra nevienodi, tačiau taip pat itin retai jie yra tik vienos pusės dispozicijoje, kai antroji neturi absoliučiai nieko. Paprastai abi pusės turi ką viena kitai pasiūlyti, kitaip nebūtų tarp jų noro derètis ar kažką mainyti. Anot E. Friedbergo (1995), žmonèms, turintiems tam tikrą sumanymą ar norintiems išspręsti kokią nors problema, reikia bendradarbiauti su kitais žmonėmis, tad jie leidžiasi į santykius su jais.

„Šiuo požiūriu galią galima apibrèžti kaip vieno veikejjo gebejjimą daugiau mažiau ilgalaikius mainų procesus struktūruoti savo naudai, pasinaudojant situacijos privalumais ir trūkumais taip, kad susiklostytų jam palankesnès mainų sąlygos. Kalba eina apie susiderėtą mainų elgseną, kuri taip sustruktūruota, kad visi mainų dalyviai ką nors iš to gauna, tačiau kažkuriam iš dalyvių (ar keletui jų) yra galimybė gauti daugiau nei likusiems" (Friedberg, 1995, 116) ${ }^{1}$.

Idomu tai, kad veikejjas (ar veikèjai) turi tuo daugiau galios, kuo nesvarbesnis jam / jiems yra vienas ar kitas derybu objektas ar problemos sprendimas. Kitaip tariant, silpnesnis ir labiau priklausomas yra tas ar tie, kuriems tai svarbu ar net gyvybiškai svarbu. Kitas galios šaltinis (šalia svarbumo / nesvarbumo) yra veikejo elgesio galimybiu laisvés laipsnis - kuo daugiau laisvès jis turi rinktis ivvairias elgesio galimybes, tuo jis galingesnis. Daugiausia galios turi tas, kuris apskritai iš mainų ar derybų santykio gali pasitraukti (Krieger, 2011).

Tad i socialinị darbą galima žvelgti, ji analizuoti ir iš mainų santykių perspektyvos. Viena vertus, mainų teorija teigia, kad reikšminga resursų asimetrija (Krieger, 2011). I socialinio darbuotojo ir kliento santykius žiūrẻdami kaip ì derybų ir mainų santykius pastebėsime, kad, nors socialinis darbuotojas dažnai ir turi didesnius resursus (išsilavinimo, žinių, materialinius, socialinio statuso) nei jo klientas, tai dar nereiškia, kad pagalbos santykis susiformuos būtent toks, kokio norètų socialinis darbuotojas. Daugiau galios turès tas, kuriam šis pagalbos santykis

\footnotetext{
1 „Aus der hier benützten Sicht kann Macht daher als die Fähigkeit eines Akteurs definiert werden, mehr oder weniger dauerhafte Tauschprozesse zu seinen Gunsten tu strukturieren, indem die Zwänge und Gelegenheiten der Situation nutzt, um die für seine Zwecke günstigen Tauschbedingungen durchzusetzen. Es handelt sich um einen verhandelten Verhaltensaustausch, der so strukturiert ist, dass alle Beteiligten etwas davon haben, wobei es aber immer einem (oder mehreren) Gegenspieler(n) möglich ist mehr herauszuholen als den anderen".
} 
nebus toks svarbus ir kuris turès laisvę iš jo pasitraukti. Jei klientas nori pagalbos ir jos siekia, o socialinis darbuotojas stengiasi ją suteikti, tuomet mainų laukia sèkmè. Tačiau neretas atvejis, kai socialinis darbuotojas siekia suteikti pagalba, o klientas dar nèra tikras, ar jam pagalbos reikia (arba galbūt jis kitaip ją įsivaizduoja nei socialinis darbuotojas). Tuomet silpnesniojo pozicijoje atsiranda socialinis darbuotojas. Galima ir atvirkštinè situacija: klientas siekia pagalbos, tačiau socialinis darbuotojas ar darbuotoja, vadovaudamasi savo pareigine instrukcija, nemano, jog turètų ją teikti.

Kita vertus, E. Friedbergo apibrèžime teigiama, kad derybų procesas priklauso ir nuo veikejjo gebejjimo palenkti mainų situaciją sau palankesne kryptimi - tai irgi yra galios resursas (pvz., socialinio darbuotojo gebejjimas sukurti su klientu toki santykị, kad pastarasis ima bendradarbiauti ir jiems pavyksta užmegzti pagalbos santyki). Kalbant socialinio darbo „kalba“, tai reikštų gerus socialinio darbuotojo gebejjimus motyvuoti klienta, o mainų teorijos „kalba“ - socialinio darbuotojo gebejjimą derybinę situaciją sustruktūruoti sau palankia kryptimi. Puiku, jei abiem šis santykis duos naudos - vienas gaus jam reikalingą pagalba, o kitas pajus pasitenkinimą savo darbu. Vis delto pagalbos santykyje slypi nemažas pavojus pasitelkti kliento bejëgiškumą ir primesti jam nepriimtinus pagalbos modelius arba iš viso jos nesuteikti. Šiam aspektui socialinis darbas turi būti itin jautrus, kad igalinanti pagalba galiausiai netaptų nugalinančia, priklausomybę sukuriančia pagalba arba net ignoravimu, pagalbos poreikio nepaisymu (nes socialinis darbas turi galią apibrèžti, kam ir kokia, kokiais atvejais pagalba teikiama). Mainų teorijos samprata apie galios santykius kaip tik ir leidžia tai analizuoti - pažvelgti i pagalbos santykius kaip i derybas ir į mainus. Žinoma, tai gal kiek svetima socialinio darbo retorikai, tačiau, kita vertus, galbūt kaip tik tai sukuria didesnę distanciją - leidžia į savo profesinę veiklą pažvelgti objektyviau. Šiame kontekste svarbus dar vienas aspektas, kuris jau minètas aptariant veberiškąją galios sampratą, kad galios turèjimas dar nereiškia pasinaudojimo ja (Weberis kalba apie galią kaip „šansą“). Vienas dalykas, anot Z. Norkaus (1998), yra galios resursų turëjimas ${ }^{1}$, tačiau visai kitas dalykas - sprendimas jais pasinaudoti. İdomus klausimas, dèl kokių priežasčių veikèjai nepasinaudoja turima galia (nors ir nedidele)? Z. Norkaus teigimu, tokios priežastys yra trys: 1) kai veikejjai nemano, kad

\footnotetext{
${ }^{1}$ Resursai čia suprantami plačiai - tarp jų ir asmens gebejjimai pasinaudoti turima galia.
} 
turi šansų laimèti; 2) kai už juos tai padaro kiti; 3) kai veikèjai viliasi būti laimingi ${ }^{1}$ - kolektyvine prasme jiems apsimoka pasinaudoti galia, tačiau individualiai jie nenori rizikuoti ir tikisi, kad tai padarys už juos kiti. Kaip matyti, galios naudojimas ar nenaudojimas labai priklauso nuo veikejjų vertinimu ar ịsitikinimu. Tai reikšmingos įžvalgos galios dirbant socialini darbą analizei. Žmonès, kuriuos ištinka krizè, kurie patiria bejejgiškuma, dažnai neieško pagalbos arba net jai priešinasi, nes netiki, kad gali kažkas pasikeisti. Tačiau lygiai tą pati galima pasakyti ir apie socialinius darbuotojus: jie gana dažnai skundžiasi neturintys tinkamų darbo sąlygų Lietuvoje, dirbantys už pernelyg mažą atlyginima, pildantys "nesuprantančios valdžios" "iš viršaus nuleistus" ", beprasmius darbus" ir pan. Mainų teorija leidžia šiais pareiškimais suabejoti. Kas tai? Galios resursų neturëjimas (pvz., susitelkti i profesinę asociaciją ir išsiderèti sau palankesnes darbo sąlygas) ${ }^{2}$, ar vis dèlto racionalus sprendimas jais nepasinaudoti dèl to, kad a priori nesitikima laimèti arba nenorima rizikuoti viliantis, kad galbūt kiti socialiniai darbuotojai, profsąjungos, asociacijos, valdžia ir pan. už juos tai padarys.

\section{SISTEMINĖ-KONSTRUKTYVISTINË GALIOS KONCEPCIJA}

Sisteminis-konstruktyvistinis požiūris i galią labai susijęs su aukščiau paminètais veikèju îsitikinimais ar vertinimais. Norint pasitelkti ši galios požiūrị, pravartu klausti - kokiu būdu įmanoma daryti poveiki sistemai ${ }^{3}$ ir ar poveikis sistemai iš išorès apskritai įmanomas? Tai esminis klausimas socialiniam darbui, kurio profesinio veikimo pagrindas yra ne kas kita kaip poveikio siekis ${ }^{4}$.

\footnotetext{
${ }^{1}$ B. Barry ir K. Dowdingas (cit. Norkus, 1998, 112) laimingu vadina tokị veikejją (individualų ar kolektyvinį), kurio politiniai interesai pasiekiami be jo įsikišimo.

${ }^{2}$ Spejama, kad Lietuvoje dirba apie 7000 socialinių darbuotojų (tikslių duomenų niekas neturi, net apie vadinamajji valstybinį sektorių, juo labiau - apie nevyriausybinį sektorių). Jei jie solidarizuotųsi, vienytųsi ir aiškiai išsakytų savo poreikius, būtų didelè jẻga.

${ }^{3}$ Sistema moderniojoje sistemų teorijoje yra suprantama plačiai: tai gali būti sąmonès / psichinè sistema (individas) arba socialinè sistema (visuomenė, grupė, organizacija, interakcija ir pan.).

${ }^{4}$ Žinoma, tai nèra vien socialinio darbo išskirtinis požymis: poveikio siekis lygiai taip pat būdingas ir kitoms pagalbos profesijoms - pedagogikai, psichoterapijai, psichologijai, konsultavimui, sielovadai ir pan.
} 
Taigi, sisteminiu-konstruktyvistiniu požiūriu, poveikis ir galia yra neatsiejami, dar daugiau - poveikis faktiškai ir yra galia (galejimas paveikti). Radikaliojo konstruktyvizmo atstovai (G. Batesonas, H. von Foersteris, P. Watzlawickas ir kt.) savo laiku suformulavo pozicija, esą galia yra mitas, metafora. Ji egzistuoja tik kaip begalio konstrukcija: galingojo galia veikia, nes begalis jam ją suteikia. Svarbu paminèti, jog dèl minètojo "galios mito" konstruktyvizmas buvo gana smarkiai kritikuojamas, esą taip pateisinama socialinè nelygybė, užmerkiamos akys prieš galingưju viešpatavimą ir engiamųjų priespaudą ir pan., kadangi už galios fenomeną atsakingi asmenys galiausiai tampa patys begaliai. Šie priekaištai visuomenès kritikos prasme tikriausiai pagristiti ${ }^{1}$, vis dèlto tai jokiu būdu nenubraukia labai svaraus konstruktyvizmo indèlio i galios fenomeno analizę.

„Galios mitas" gimsta iš esminės konstruktyvizmo prielaidos² apie gyvas sistemas kaip save kuriančias (autopoetines), save struktūruojančias ir informacine prasme aplinkai uždaras sistemas. Anot konstruktyvizmo, joks tiesioginis poveikis sistemai iš išorès nèra įmanomas. Veikiama iš išorès sistema gali patirti (ir patiria) vadinamąsias perturbacijas, tačiau kokios bus tų perturbacijų pasekmės, priklausys tik nuo pačios sistemos

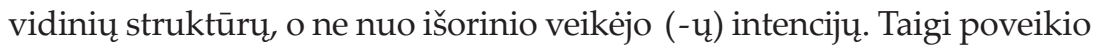
rezultatas niekaip negali būti kontroliuojamas iš išorès. Trumpai tariant: sistema iš išorès negali būti valdoma ar instruktuojama be pačios sistemos pritarimo $^{3}$ (plg. Krieger, 2011, 54 ir t.). Iš čia ir "galios mitas": galia iš išorès veikia tik esant vidiniam sistemos pritarimui - jokiu kitu būdu instruktuojamoji interakcija nèra i̇manoma. Visa tai itin reikšminga socialiniam darbui, kurio veiklos esmė yra būtent instruktuojamoji interakcija.

Vis dèlto B. Krausas (2011), nors ir pritardamas konstruktyvizmo „galios mitui“, atkreipia demesi, kad tik instruktuojamosios galios atveju galia yra vadinamojo begalio konstruktas - ji negalima be jo sutikimo (pasidavimo ar pritarimo). Visai kitaip yra destruktuojamosios galios

\footnotetext{
${ }^{1}$ Nes radikaliojo konstruktyvizmo atstovai neanalizuoja socialinių galios struktūrų atsiradimo prielaidų.

2 Šia prielaida vadovaujasi ir modernioji sistemų teorija (pvz., N. Luhmanno socialiniu sistemų teorija).

3 „Pritarimu“ čia gali būti laikomas ir nusižeminimas, pasidavimas, prisitaikymas, paklusimas ir pan.
} 
atveju - ji veikia ir be begalio sutikimo. Taigi B. Krausas įveda svarbią skirti - instruktuojamoji galia versus destruktuojamoji galia. Ši galios formų diferenciacija labai reikšminga socialiniam darbui. Anot B. Krauso (2011), kokybini šių abieju galios formų skirtumą išryškina būtent pasipriešinimo galimybè. Destruktuojamosios galios atveju begalis negali jai priešintis, o instruktuojamosios galios atveju jis tikrai tokią galimybę turi, nes instruktuojamoji galia tik tuomet ir tesuveikia, jei vadinamasis begalis jai pritaria. Destruktuojamoji galia gali būti taikoma tiek fizine, tiek kognityvine prasme. Socialiniam darbui ši galios rūšis tikrai nėra retenybė: pvz., tèvų valdžios apribojimas; vaiko paėmimas iš šeimos siekiant ji apsaugoti; priverstinè asmens hospitalizacija; priverstinis seno ar neigalaus asmens apgyvendinimas globos institucijoje - visa tai būtų destruktuojamosios galios pavyzdžiai fizine prasme. Kognityvine prasme destruktuojamoji galia yra, pvz., tam tikros informacijos nepasakymas, asmens neįtraukimas i komunikacijos procesus ir pan. Visa tai irgi yra sutinkama dirbant socialini darba, beje, ne tik mezgant santykius su klientais, bet ir socialinio darbo santykius su kitomis profesijomis ar institucijomis (pvz., Lietuvoje dažnas atvejis, kai Vaiko teisių apsaugos skyrius, priimdamas sprendimą dèl vaiko paėmimo iš šeimos ir apgyvendinimo globos institucijoje, socialinio darbuotojo nesikviečia, nors šis dirba su šeima ir dažnai šeimos situacija jam yra žinoma geriau. Taigi - nebendradarbiavimas, informacijos neperdavimas, nesitarimas ir pan. yra destruktuojamoji galia). Apibendrinant: destruktuojamoji galia reiškia sistemos (asmens, grupės, organizacijos) galimybiu apribojima, redukavima. Tačiau tik tai ir nieko daugiau: ją naudojant galima pasiekti, kad sistema kažko nedarytu, tačiau negalima pasiekti, kad sistema kažką darytu, - nes tai jau instruktuojamosios galios atvejis ${ }^{1}$. Beje, destruktuojamoji galia yra visiškai saugi rezultato prasme. Pavoju kitiems keliamo asmens izoliavimas iš tiesų apsaugo nuo galimo pavojaus fizine prasme. Tai labai svarbus aspektas analizuojant galios santykius socialinio darbo

\footnotetext{
${ }^{1}$ Destruktuojamoji galia garantuoja, kad, pvz., vaikams nieko blogo šeimoje nebenutiks, nes jie paimti iš šeimos, kadangi jiems grèsė pavojus. Tačiau vaikų atėmimas iš tèvų (destruktuojamoji galia) visiškai negarantuoja, kad tèvai pasikeis, supras savo klaidas, ims kitaip žiūrèti i savo pareigas ir t. t. Visa tai jau yra instruktuojamosios galios atvejis, o ji suveikia tik tuomet, jei tèvai įžvelgia kokią nors viso to prasmę. Žinoma, jie gali apsispręsti keistis būtent todèl, kad išsigąsta galutinai neteksiantys vaiku, tačiau net ir šiuo atveju poveikis jiems yra įmanomas tik dèl jų pačių vidinio apsisprendimo.
} 
kontekste. Pvz., ar vaikas iš šeimos paimamas, nes taip geriau jo raidai, ar todèl, kad taip ramiau Vaiko teisių apsaugos skyriui, nes jeigu kažkas nutiktų vaikui, atsakomybę tektų prisiimti būtent vaiko teisių specialistams. Instruktuojamosios galios atveju viskas atvirkščiai - ja siekiama praplèsti sistemos veikimo galimybes, o ne jas redukuoti (pvz., mokant tèvus kitokio elgesio su savo vaikais), tačiau ši galia yra visiškai nesaugi rezultato prasme dèl jau minètos priežasties - ji veikia tik esant kliento sistemos vidiniam pritarimui. Tai vèlgi labai reikšmingas socialinio darbo aspektas: instruktuojamoji galia yra nuolatinis šios profesinès veiklos siekis ir kartu faktiškai dažniausiai pasitaikanti interakcija (visi socialinio darbo metodai yra instruktuojamosios intervencijos), tačiau jie visiškai negarantuoja sėkmės, taigi nėra saugūs rezultato prasme. Kitaip tariant, socialinio darbo rezultatai nèra ir negali būti kontroliuojami pačių socialinių darbuotojų, nors to galbūt iš jų ir tikimasi.

Vis dèlto, kaip teigia B. Krausas, „nors instruktuojamajai galiai yra būtinas sistemos pasidavimas ir ji gali būti mąstoma tik kaip socialinis konstruktas, tačiau instruktuojamoji galia mezgantis socialiniams santykiams kaip tik ir yra paveiki būdama būtent toks konstruktas" (2011, 107). Instruktuojamoji galia yra socialinis fenomenas, kuris instruktuojamą sistemą priverčia elgtis prieš savo valią ir paklusti instrukcijoms. Tai, anot B. Krauso (2011), leidžia pilniau ir kitame kontekste suprasti aukščiau cituotą M. Weberio galios apibrėžima, kad „galia reiškia bet koki šansą socialiniame ryšyje realizuoti savo valią - taip pat ir tuo atveju, kai susiduriama su pasipriešinimu (...)“ $(1976,28)$.

M. Krüll savo tekste (cit. Krieger, 2011, 66 ir t.) atkreipia dėmesi i $i$ „galios mito" komunikacines naudas ir į tai, kokią galią turi komunikavimas apie galią - taigi galios metakomunikacija. "Galios mitas" tiek galingajam, tiek begaliam suteikia ir privalumų, ir trūkumų. Galingasis turi galia, nedėdamas pernelyg daug pastangų, nes, kaip minèta, galią jam suteikia begalis. Tačiau minusas yra atsakomybè, kurią galingasis gauna. Tuo tarpu begalis kaip tik šią atsakomybę nuo savęs nusiima (tai privalumas, nes yra saugu, nereikia rizikuoti, negali būti apkaltintas ir pan.), už viską atsakingu padarydamas galingajij. Tačiau minusas yra tai, jog begalis praranda galimybę realizuoti save, įsitraukti, dalyvauti, kurti ir pan. Apie ši aspektą rašè jau G. Batesonas (1997) - vienas radikaliojo konstruktyvizmo kūrẻjų. Jo nuomonė griežta: "galia pati savaime nèra 
tiek korumpuota kiek mitas apie galią“ (223). Šis fenomenas neretai sutinkamas psichoterapiniuose ar socialinio darbo kontekstuose ir žinomas kaip „išmokto bejègiškumo“, „klientelizmo" reiškinys. „Galios mito" komunikacines naudas būtų įdomu pasitelkti ir socialinių darbuotojų padèties Lietuvoje analizei. Kaip minèta, iš socialinių darbuotojų dažnai girdima apie jų bejėgiškumą valdžios ar kitų institucijų, kitų specialistų atžvilgiu. Galbūt tai yra faktas (pvz., kad socialiniams darbuotojams Lietuvoje teisės aktai suteikia mažiau galių nei kitose šalyse), tačiau, kita vertus, galbūt tai mitas, socialiniams darbuotojams teikiantis daugiau privalumų nei trūkumų? Juk iš esmès, pvz., reikiamų teisès aktų atsiradimą galètų inicijuoti patys socialiniai darbuotojai. Tačiau tam reikètú papildomų pastangu, tektų rizikuoti, konfrontuoti, galų gale, sèkmès atveju, nebeliktų pasiteisinimo, kad socialinių darbuotojų niekas nepaiso ir pan.

Anot M. Krüll (cit. Krieger, 2011, 66 ir t.), „galios mitas“ geriausiai veikia, kai jis nèra analizuojamas, kai apie ji nẻra kalbamasi (galia turi būti jaučiama, bet aiškiai neịvardijama). Turbūt todèl "galios mitas" yra gajausias tabu kontekstuose, autoritarinėse struktūrose ar totalitarinèje aplinkoje (H. Arendt (2001) formuluoja, esą prievarta prasideda ten, kur baigiasi kalbëjimas). Vis dèlto, jei konkrečioje situacijoje yra užduodamas klausimas apie galią, kelio atgal nebèra - tai nebegali neturèti poveikio. Anot M. Kriegerio (2011), šiuo požiūriu tai turbūt esmingiausia konstruktyvizmo iž̌valga. Anot jo, komunikavimas apie galią jau savaime verčia ją analizuoti: galios santykius, galios resursus, galios šaltinius, priklausomybes ir t. t. $\mathrm{O}$ analizė atneša pokyti (nebūtinai, žinoma, vien teigiamą). Po tokių analizių ar refleksijų neįmanoma, kad viskas būtų kaip prieš tai - sistemos privalès savo santykius permąstyti ir struktūruoti kitaip. Taigi komunikavimas apie galią - galios metakomunikacija - išryškejja kaip svarbi galios priemonè.

\footnotetext{
${ }^{1}$ Situacijos, kai klientams paranku būti bejëgiams, todèl jie sabotuoja bet kokius bandymus padèti. Pvz., jei ilgametis depresija sergantis pacientas pasveiktų, jam tektų eiti dirbti, nebegautų neigaliojo pašalpos, nebetektų daugelio pasiteisinimų ir pan.
} 


\section{GALIOS ŠALTINIAI, FORMOS IR PRIEMONÉS}

Aptarus keletą galios teoriju momis ir priemonėmis. W. Kriegeris (2011, 52 ir t.), susiedamas tarpusavyje V. Krumrey, H. Popitzo, J. K. Galbraitho darbus, apibrėžė penkias pagrindines galios formas bei šaltinius (žr. 1 schemą).

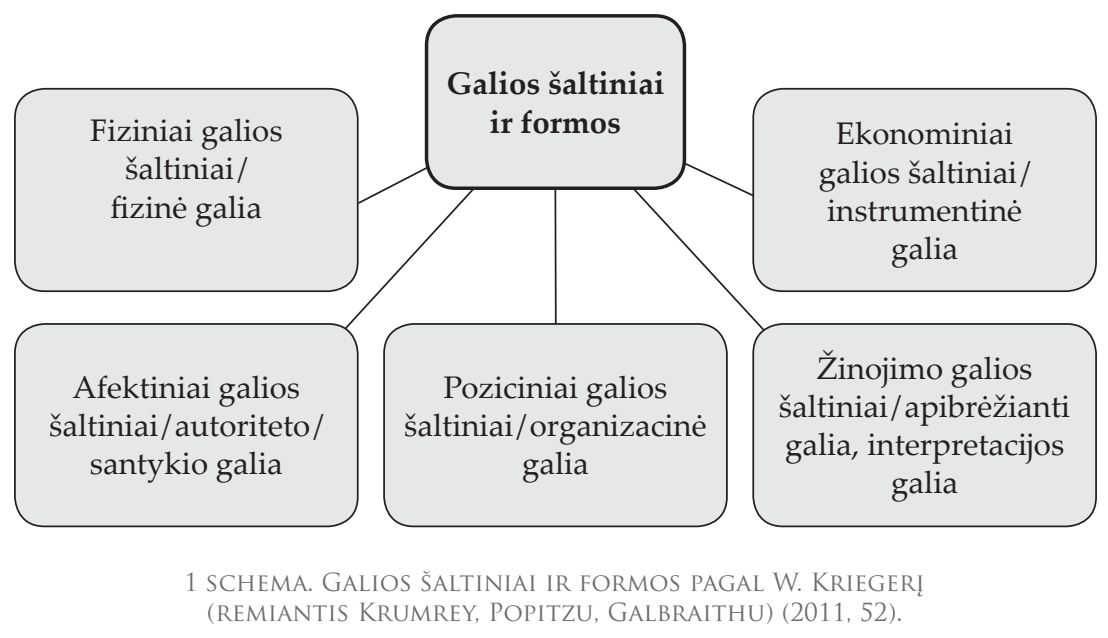

Visos penkios galios formos, kurios veikia ir kaip galios igyvendinimo priemonès, yra reikšmingos socialiniam darbui ir gali būti pasitelkiamos galios santykių dirbant socialinį darbą analizei.

Fizine galia atsiranda iš fizinès persvaros arba tuomet, kai galingasis turi teisę imtis fizinès prievartos. Dirbant socialinį darba, jau minèta ${ }^{1}$, fizinės galios atvejai nėra itin reti, nors ji, žinoma, turètų būti taikoma kaip kraštutinė priemonè. Pavyzdžiui, priverstinis apgyvendinimas globos institucijoje, tèvų teisių apribojimas ir vaikų paėmimas iš šeimos, priverstinè hospitalizacija ir pan. yra fizinės galios atvejai. Netgi socialinio (-ès) darbuotojo (-os) apsilankymas kliento namuose (ar globos institucijoje gyvenančio asmens kambaryje) yra fizinės galios išraiška, nes jis / ji îsiveržia i̇ asmens privačią erdvę. Fizinè galia taikoma siekiant kliento gerovès, nors dažnai tai reiškia, kad veikiama prieš jo valią.

${ }^{1}$ Aptariant destruktuojamąją galią (žr. aukščiau). 
Ekonomine arba instrumentine galia atsiranda tuomet, kai galingasis turi begaliui reikšmingų resursų. Anot Kriegerio (2011), ekonominè galia pasižymi tuo, kad galingasis, suteikdamas resursus, sieja juos su tam tikromis salygomis. Tokiu būdu ekonominè galia pavirsta represyviomis (pvz. baudimas, gąsdinimas, grasinimas) arba kompensuojančiomis (skatinimas, apdovanojimas) interakcijomis. Tad ekonominè galia dar gali būti suprantama kaip „baudžiamoji galia“ bei „apdovanojamoji galia" (Paris cit. Krieger, 2011, 53). Ekonominès galios apraiškos, be abejo, būdingos socialinio darbo laukui. Socialinio darbo organizacijos sprendžia (arba gali daryti įtaką sprendimams) dèl resursų (pvz., pašalpos, paramos, labdaros, socialinio būsto, nematerialių paslaugų ir pan.), kurie yra reikšmingi klientui. O represinès arba kompensuojamosios interakcijos yra taikomos siekiant bei tikintis kliento pokyčio (pvz., mažinti parama, jei klientas su ja elgiasi netinkamai; bedarbio pašalpa mokama tik tam tikrą laikotarpi, skatinant greičiau įsidarbinti; vaiko dienos centre vaikas, surinkęs tris pliusus už gerą elgesį, gali vykti ị ekskursiją ir pan.). Ekonominės galios apraiškos būdingos ne tik tiesioginiam darbui su klientais, bet ir paties socialinio darbo kontrolei. Socialinio darbo organizacijos yra priklausomos nuo jų finansavimo šaltinių (valstybès, savivaldybès, fondu, aukotojų ir pan.) diktuojamų sąlygų - taigi nuo jų ekonominès galios.

Autoriteto arba santykio galia atsiranda iš galingesniojo gebejjimo patenkinti kito asmens afektinius poreikius (Krieger, 2011). Ši galios forma remiasi pasitikejjimu ir yra labai svarbi ne tik socialiniam darbui bei kitoms pagalbos ar pedagoginėms profesijoms, bet ir neformaliems santykiams.

Autoriteto galia labai susijusi su autoriteto fenomenu bei jo poveikio mechanizmu, todèl pravartu i tai kiek labiau įsigilinti. Anot H. Popitzo (1986), autoriteto fenomenas yra specifinis asmens priklausymas nuo to, ką kitas daro arba ko jis nedaro. Nuo autoriteto priklausomas asmuo ji nuolat stebi, reaguoja $i \mathrm{j} i \mathrm{i}$, ypač jam svarbu tie autoriteto veiksmai, kuriuos supranta kaip jo reakciją i save. H. Popitzo įsitikinimu, autoriteto fenomenas yra giluminis psichologinis reiškinys, susijęs su nuo autoriteto priklausomo asmens savęs paties vertinimo poreikiu. Socialinis pripažinimas (šiuo atveju, iš autoriteto gautas pripažinimas) yra būtinas vidinès savivertès struktūrai. Taigi galima daryti prielaidą kad be socialinio pripažinimo nesiformuoja, neauga vidinis savęs 
vertinimas - savivertè. Arba kitaip - socialinės pripažinimo patirtys nulemia savęs pripažinimo ir vertinimo struktūra, ne atvirkščiai. Tad autoriteto poveikio mechanizmas atrodo taip: asmuo siekia jam reikšmingo autoriteto pripažinimo (taigi - socialinio pripažinimo), tačiau giluminis asmens poreikis yra pripažinti, vertinti pati save. Tai H. Popitzas vadina „universalia antropologine struktūra" $(1986,20)$. Stebint autoritetinio ryšio atsiradima, matyti dvejopas pripažinimo procesas: pirmiausia asmuo išsirenka, pripažista jam kažkuo ypatingą asmenį, o po to siekia, kad pasirinktas autoritetas išskirtinai pripažintu ji. Anot H. Popitzo, autoritetinių santykių psichologinè struktūra gerai paaiškina, kodèl autoritetas tampa toks paveikus. Todèl, kad jis valdo asmeni gilumine prasme (net ir tada, kai paties autoriteto nèra šalia fiziškai) - žmogus ima elgtis taip, kaip norètu jo autoritetas, jis persiima jo vertybemis ir normomis, netgi gali panašiai kalbèti, rengtis, turèti tokius pačius daiktus. Kyla klausimas, kada iš autoritetinių ryšių ir priklausomybės nuo autoriteto atsiranda autoriteto galia? H. Popitzo įsitikinimu, autoriteto galia ima veikti tuomet, kai asmens pripažinimo poreikiais ir jo demesio sukaupimu i autoritetą yra sąmoningai pasinaudojama, siekiant asmens elgesio ir nuostatų pokyčio. „Autoriteto galios igyvendinimo metodai yra pripažinimo bei pripažinimo lūkesčių (vilčių, baimių) suteikimas ir nesuteikimas" (1986, 34).

Suprantama, kad autoriteto galia vaidina labai reikšmingą vaidmeni visuose pedagoginiuose kontekstuose - tarp jų ir socialinio darbo kontekste. Jei socialinei darbuotojai ar darbuotojui pavyksta tapti reikšmingu asmeniu ar net autoritetu savo klientui, atsiveria galimybės sėkmingai instruktuojamajai sąveikai. Asmuo ima elgtis kitaip, jo nuostatos keičiasi dèl autoriteto jam turimos galios - noro būti autoriteto pripažintam, ivertintam, arba atvirkščiai - iš baimès to pripažinimo ar ivvertinimo nesulaukti.

Pozicine arba organizacine galia atsiranda iš asmenų vaidmenu, kuriuos jiems suteikia organizacija (Krieger, 2011). Vaidmens turètojas (galingasis) privalo vykdyti tam tikras pareigas, tačiau jis turi ir tam tikras teises. Mažiau galingas (organizacinio vaidmens neturintis) klientas, siekdamas pasinaudoti organizacijos teikiamais privalumais, privalo paklusti taisyklėms, procedūroms, prisiimti atsakomybes ir pan. Socialinio darbo atveju pozicinė arba organizacinè galia yra itin reikšminga. Ši galios forma veikia esant bet kuriam socialinio darbuotojo ir kliento santykiui. 
Socialinio darbuotojo vaidmuo dažnu atveju suteikia jam teisę ne tik apibrèžti, kokią problemą (-as) turi klientas (taigi - socialinis darbuotojas turi definicijos galią), bet ir nuspręsti, kokio pobūdžio pagalba ir kiek jos klientui gali būti siūloma. Kita vertus, pozicinẻ ar organizacinė galia gali turèti ir neigiamu pasekmiu pagalbos procesams - jau vien todèl ji verta išsamių empirinių tyrinèjimų. "Lazda turi du galus" - socialiniai darbuotojai, turèdami organizacinius vaidmenis, privalo paklūsti organizacinėms taisyklèms bei rutinoms, pagalbos teikimo biurokratijai. Tai, kas neformalioje aplinkoje nesudarytų didesnių sunkumų, formalizuotose, biurokratizuotose struktūrose gali tapti didele problema ${ }^{1}$. Dar vienas aspektas: jei socialinis darbas pernelyg persiima organizacine galia, jis rizikuoja pasiekti tik tuos klientus, kurie linkę šiai galiai paklūsti, nes siekia per ją gaunamų resursų ${ }^{2}$. Klientai, kurie nemano turintys pagalbos poreikių (nes, pvz., negali kritiškai vertinti savo situacijos), i formalizuotas struktūras nesikreipia ir socialinių darbuotoju disponuojama organizacine galia nepasinaudoja.

Žinojimu besiremianti galia atsiranda, kai vienas asmuo turi daugiau informacijos, žinių, supratimo nei kitas ir todèl pelno silpnesniojo, mažiau galios turinčiojo pripažinimą. Socialinio darbo atveju ši galios forma koreliuoja su pozicine ar organizacine galia - socialinio darbuotojo vaidmuo suteikia jam vadinamają definicijos galia - turimų žinių ir patirties pagrindu nuspręsti, i̇vardyti, kokios kliento sistemos problemos ir kaip jos bus sprendžiamos. W. Kriegeris (2011) kalba apie trejopo pobūdžio socialinių darbuotojų definicijos galią: analitinę, programinę ir vertinamają. Socialinis darbuotojas analizuoja kliento situaciją ir nustato jai „diagnozę", tada jis numato (taigi sudaro programą) galimus problemos

\footnotetext{
${ }^{1}$ Pvz., Lietuvos kaimiškose teritorijose didelè problema yra paprasčiausias susisiekimas - visuomeninio transporto tinklas pernelyg mažai išplètotas, o socialinio darbo klientai dažnai neturi nuosavo transporto ar pinigų degalams, o socialinès, medicinos, švietimo paslaugos dažniausiai teikiamos didesniuose centruose. Pagal galiojančius nuostatus, socialinė darbuotoja negali savo klientų pavežti (netgi krizių atvejais) savo transportu, nes pavéžejimas neįeina i̇ jos teikiamas paslaugas, tam nẻra skiriama lešų ir t. t.

2 Taip, pvz., yra nutikę dirbant socialinį darbą su rizikos šeimomis Lietuvoje. Nors socialiniai darbuotojai ir dirba su šeimomis, patiriančiomis krizes, tačiau jų darbo valandos yra kaip ir visų valstybinių ịstaigų tarnautojų - pirmadieniais - penktadieniais nuo 8 iki 17 val. su fiksuota pietų pertrauka. Tuo tarsi deklaruojama, jog krizè, kuri šeimas ištinka vakarais ar naktimis, švenčių dienomis, - negalioja. Kyla klausimas, kokias funkcijas pozicinè, organizacinè galia šiuo atveju iš tiesų atlieka?
} 
sprendimo būdus ir galiausiai apibrèžia vertinamąja prasme - ivvardija pagalbos konkrečiu atveju sẻkmès ir nesèkmès kriterijus.

Anot W. Kriegerio (2011), ši penktoji, žinojimo galios forma skiriasi nuo pirmujų keturių. Fizinè, ekonominè, autoriteto bei pozicinè galia yra pakankamai skaidrios - ju atveju galios turètojai privalo pagristi savo taikomą galia, ją paaiškinti, jei jo tikslas tinkamai suorientuoti asmenų pagalbos lūkesčius. Žinojimo galia yra kiek kitokia, ja išreiškiamas ne galingesniojo noras, bet kokia nors duotybè (pvz., įstatymas, mokslinė teorija, egzistuojanti pagalbos teikimo praktika, konkrečiai problemai spręsti valstybejje egzistuojančios paslaugos ir t. t.). Kaip tik ši galios forma dažnai gali slėpti egzistuojančias socialinès nelygybès, socialinio neteisingumo struktūras ${ }^{1}$. Todèl ši galios forma, besireiškianti dirbant socialinį darba, turètų būti itin atidžiai analizuojama.

Baigiant svarbu pabrèžti, kad dirbant socialinį darbą visos paminètos penkios galios formos pasižymi ambivalencija. Fizinè, ekonominè, autoriteto, pozicinè ir žinojimo galia gali būti naudojamos tiek pagalbai, tiek kontrolei. Taigi šios socialinių darbuotoju galios yra ir pagalbos instrumentas, ir tuo pat metu kontrolès instrumentas. Riba tarp pagalbos ir kontrolès yra labai sunkiai apčiuopiama - kokie kriterijai konkrečios pagalbos istorijos atveju lemia, ar socialinis darbuotojas naudoja galią kliento atžvilgiu siekdamas padèti, ar siekdamas kontroliuoti, ir kuriuo momentu pagalba virsta kontrole ir galbūt atvirkščiai? İtampa tarp pagalbos ir kontrolès yra socialinio darbo profesijos duotybè - jos vadinamoji dvigubo mandato dilema ${ }^{2}$ - šioje profesijoje visuomet bus ir

\footnotetext{
${ }^{1}$ Pvz., Lietuvoje labai trūksta diferencijuotuc paslaugu psichikos bei proto negalią turintiems asmenims. Jei, nors ir nelabai dideli sutrikimą turintis asmuo yra vienišas ir niekas iš artimujų nepadeda jam susitvarkyti buities, išeitis faktiškai viena - būti apgyvendintam globos institucijoje iki gyvos galvos, nes jokios kitos paslaugos, leidžiančios tokiam asmeniui gyventi savarankiškai savo natūralioje aplinkoje, neteikiamos. Tai galima traktuoti kaip žmogaus teisių pažeidimą (nes globos institucijoje žmogus netenka galimybès visaverčiai dalyvauti visuomenės gyvenime, turi atsisakyti savo savarankiškumo ir t. t.), tačiau taip pat galima pateikti kaip ,duotybę", ,vienintelę ir geriausią išeitį“. Ne paslaptis, kad, siekiant „spręsti“ šių žmonių problemas, pasitaiko atveju, jog psichikos ar proto negalią turinčių asmenų diagnozès yra "pastiprinamos“, atskirais atvejais iš jų net atimamas veiksnumas, nes „nèra kur kitur jų padėti“...

2 Socialinio darbo "dvigubo mandato dilemą" pirmą kartą apibrèžè L. Bönischas ir H. Löschas (1973). Dvigubas mandatas reiškia, kad socialiniai darbuotojai yra priversti „išlaikyti nuolat pažeidžiamą pusiausvyrą tarp, viena vertus, klientų teisių, poreikių ir interesu, kita vertus, tarp socialinès kontrolès interesų, kurių siekia viešojo valdymo institucijos" (Bönisch, Lösch 1973, cit. pgl. Spiegel, 2008, 37).
} 
vieno, ir kito. Todèl pagalbos ir kontrolès santykio analizė bei ju balanso paieškos yra ir socialinio darbo galios balansu paieškos, prisimenant aukščiau minètą N. Eliaso galios balansų koncepciją.

\section{APIBENDRINIMAS IR EKSKURSAS}

Kaip galima būtų apibendrinti, kas yra galia? Anot Z. Norkaus (1998), tai beveik neįmanomas uždavinys. Turbūt neatsitiktinai nėra vienos galios teorijos, yra daugybẻ požiūrių (retas didžiưjų vardų nẻra bent užsiminęs apie galią - straipsnyje paminèti vos keli iš jų), iš dalies vienas kitam net prieštaraujančių. Iš tiesu, galios fenomenas turi pernelyg daug „veidų“, kad sutilptų i vieną teorinę paradigmą (ar bent kelias).

Tad galios tyrinètojas visuomet turès apsispręsti, kuriuos aspektus ir kokiu požiūriu jis tiria, nes visuma neįmanoma. Tačiau teorinių prieigų eklektika (net jei neišbaigta) yra veikiau jo privalumas nei minusas, nes leidžia siekti didesnio kompleksiškumo. Viena aišku, kad svarstymai apie galią turi remtis konkrečių santykių analize, nes tik iš jų ji ir gimsta iš konkrečiu tarpusavio santykių ir konkrečios patirties. Juo labiau, jei tyrimais siekiama ne vien konstatuoti, bet ir pokyčio - galios santykių persistruktūravimo. Kaip minèta, jau pats kalbẻjimas apie galią yra galia. Socialinis darbas, kuris gilinasi i savo paties galia, turi šansą ne vien ją pažinti, bet ir, kai reikia, stiprinti, o kai nevalia - mažinti.

\section{LITERATŪRA}

1. Arendt, H. (2001). Totalitarizmo ištakos. Vilnius: Tyto alba.

2. Bateson, G. (1979). Mind and Nature. A Necessary Unit. New York: Chandler Publishing Company.

3. Baumann, P. (1993). Macht und Motivation. Zu einer verdeckten Form sozialer Macht. Opladen.

4. Elias, N. (1986): Was ist Soziologie? 5 Aufl. Muenchen.

5. Friedberg, E. (1995). Ordnung und Macht. Dynamiken organisierten Handelns. Frankfurt / NY.

6. Kraus, B. (2011): Soziale Arbeit - Macht - Hilfe und Kontrolle. Die Entwicklung und Anwendung eines systemisch-konstruktyvistischen Machtmodels. Kraus, B., Krieger, W. (Hrsg.). Macht in der Sozialen Arbeit. Magdeburg: Jacobs Verlag. 
7. Kraus, B., Krieger, W. (2011). Zur Einführung - Die Reflexion Sozialer Arbeit im Lichte von Theorien zur Macht. Kraus, B., Krieger, W. (Hrsg.). Macht in der Sozialen Arbeit. Magdeburg: Jacobs Verlag.

8. Krieger, W. (2011). Macht jenseits der konstruierten Selbstunterwerfung? Kraus, B., Krieger, W. (Hrsg.). Macht in der Sozialen Arbeit. Magdeburg: Jacobs Verlag.

9. Krüll, M. (1986). Ist die „Macht“ der Männer im Patriarchat nur eine Methapher? Zeitschrift für systemischen Therapie 4. 1986: 226-231.

10. Norkus, Z. (1998). Du galios veidrodžiai. Politologija, 1998, 1 (11): 103-116.

11. Popitz, H. (1986). Phänomene der Macht. Autorität - Herrschaft - Gewalt Technik. Tübingen: J. C. B. Mohr (Paul Siebeck).

12. Ruškus, J., Mažeikis, G. (2007): Neigalumas ir socialinis dalyvavimas. Kritine patirties ir galimybiu Lietuvoje refleksija. Šiauliai: Šiaulių universiteto leidykla.

13. Spiegel, H. v. (2008). Methodisches Handeln in der Sozialen Arbeit. München und Basel: Ernst Reinhardt Verlag.

14. Weber, M. (1976): Wirtschaft und Gesellschaft: Grundriss der verstehenden Soziologie. Tübingen: J. C. B. Mohr (Paul Siebeck).

15. Wolf, K. (1999). Machtprozesse in der Heimerziehung. Band 2. Münster: Votum Verlag.

16. Wolf, K. (2011). Zur Notwendigkeit des Machtüberhangs in der Erziehung. Kraus, B., Krieger, W. (Hrsg.). Macht in der Sozialen Arbeit. Magdeburg: Jacobs Verlag.

17. Žiliukaitė, R., Ramonaitė, A., Nevinskaitè, L., Beresnevičiūtè, V., Vinogradaitè, V. (2006). Neatrasta galia. Lietuvos pilietinés visuomenés žemèlapis. Vilnius: Versus Aureus.

\section{SUMMARY}

\section{SOCIAL WORK AND POWER: THEORETICAL BACKGROUND FOR RESEARCH}

Power and social work are concurrent, because every help (every relation) are always related with power and dependency. A research of phenomenon of power in social work almost hasn't existed in Lithuania till now. The research could be unfolded on three levels: micro - the level of social work intervention, mezzo - the level of organization of social work, and macro - the level of power of social work profession in the society. The paper aims to discuss fundamental concepts and several theoretical approaches for potential theoretical and empirical 
research of power in social work. M. Webber's classical concept of power; $\mathrm{N}$. Elias' theory of power balance; approaches toward power in theories of games and social exchanges; and systemic-constructivist concept of power are analysed in the paper. Also five forms of social work power, which at the same time are the sources of social work power and the means of exercising the power, are more closely discussed in the paper. These are physical power, economical or instrumental power, authority or relationship power, positional or organizational power, knowledge or definition power. The last one is worth of close analyse, because it can hide, justify, or seek to embed structures of social inequality, injustice, and violations of human rights. And at last from the discussions based on systemic-constructivist perspective in the paper becomes evident that communication about power or power meta-communication is another specific source of power. If the question of power in specific relationship is raised there is no the way back, and nothing can stay as it used to be, because it forces towards a movement and change, which, by the way, can be positive as well as negative. This is one of the reasons, why an analysis of power phenomenon in social work is always relevant and even necessary. 